\title{
Central Bank Communication and Policy Interest Rate
}

\author{
Haryo Kuncoro ${ }^{1}$ \\ ${ }^{1}$ Faculty of Economics, State University of Jakarta, Indonesia \\ Correspondence: Haryo Kuncoro, Faculty of Economics, State University of Jakarta, Indonesia. \\ Received: May 21, 2020 \\ Accepted: July 17, 2020 \\ Online Published: December 24, 2020 \\ doi:10.5430/ijfr.v12n1p76 \\ URL: https://doi.org/10.5430/ijfr.v12n1p76
}

This research is financially supported by Lembaga Penelitian UNJ under contract No. 5/GB-UNJ/LPPM/V/2020.

\begin{abstract}
Central bank communications play an important role in the monetary policy. In the inflation-targeting frameworks, central bank communications might guide public to shape inflation expectations and then determine actual inflation rates through which the policy interest rates policy would manage them. This paper studied the impact and central bank monetary policy communications on the policy interest rate. Unlike other studies, this paper uses two stages. First, we estimate the impact of central bank communication on the inflation expectation gap. Second, we use the estimated value of inflation expectation gap to predict the policy interest rate. The study found evidence that economic agents analyse the Governor Board of Central Bank of Indonesia meeting decisions every month to shape their inflation expectation. Therefore, the difference between inflation expectation and actual inflation tends to narrow. The inflation expectation gap affects the policy interest rates in Indonesia. In other words, the policy interest rates can control the inflation rate and anchor expectations as required by the inflation-targeting framework.
\end{abstract}

Keywords: central bank communication, text mining, inflation expectation gap, Taylor rule, policyinterest rate

JEL Code: E52, E58, E32, E61

\section{Introduction}

Monetary policies play an important role in the economy to help in achieving the desired macroeconomic goals. Before 1990, various aspects of the monetary policy decision-making process were largely kept secret (Su et al., 2019). Demands for policy transparency require the central bank to reveal the secrecy of those policies (Geraats, 2006). As a result, the central bank began to emphasize transparency, especially since the application of rule-based monetary policy. Central bank communication on the monetary policy formulation process and implementation has been increasingly used in managing market expectations (Amato et al., 2002).

Central bank communication is also a key instrument in the inflation-targeting policy. Since the central bank has to announce the inflation target in advanceand the private sector appraises the future reliability of this target, communication is crucial for the expectation formation process (Svensson, 1999). The literature intensively highlights that the clarity of communication provides information that improves the perception ofthe public regarding the central bank's inflation targets (Blinder et al., 2008). Therefore, the usefulness of monetary policy signalling to economic agents in decision-making determines dispersion between the inflation target and the actual inflation.

The commitment of the central bank to the target is another aspect to reach successful inflation-targeting policy implementation. In the inflation-targeting regime, central banks utilise inflation targets as a nominal anchor to form economic agents' expectations. Tying up inflation expectations to inflation targets compared to actual inflation inevitably boosts the monetary policy credibility. In such a case, the central bank needs to identify whether the expected inflation is performed by forward-looking or backwards-looking mindset. The inability of central banks to recognize the expected inflation causes the target inflation set by the central bank can be unachievable and therefore potentially generates future inflation uncertainty (Montes and Curi, 2017).

However, as we shall see, the empirical studies which are incorporating the actual-expected inflation gap and the actual-targeted inflation gap in the policy interest rate give the diverging results, especially in the low inflation countries. In the low inflation economies, inflation expectations are not as well tied up as when inflation is around 
the target. Consequently, inflation expectations are more conditional on actual inflation. The inflation expectations revise down in accordance with lower-than-expected inflation rates but do not react to higher-than-expected inflation rates. This prompts that central banks should look forward to inflation expectations to act diversely than was the case early when inflation was often quite near target in many developed countries (Ehrmann, 2015).

The convergence of inflation expectations toward inflation targets rather than actual inflation helps the central banks to set policy interest rate effectively. It is argued that the policy interest rate can control only the short-term nominal interest rates whereas the agent economic decisions depend on the long-term real interest rate expectations (Hansen and McMahon, 2016). Hence, a greater monetary policy accountability induced by the central bank communication could provide an efficient mechanism to link the two types of interest rates (Tomuleasa, 2015). In such a case, whether the clarity of the information content of the central bank announcement would be an appropriate direction for the future policy guide of the economy has to be addressed first to improve monetary policy transmission mechanisms, which in turn affects to the real economic sectors.

Indonesia provides an excellent opportunity to investigate the natures of the inflation target, expected inflation, and actual inflation rates. Following the 1997/1998 Asian financial crisis, Indonesia experienced skyrocketing inflation along with dropping economic activities. However, after implementing inflation-targeting frameworks in her monetary policy, Indonesia since 2005 has been enjoying the low and stable inflation rates. The low and stable inflation rates below the target rates in recent years (see Figure 1) raises the question of whether the central bank monetary policy communications are effective in managing public inflation expectations. Accordingly, the monetary policy in terms of the benchmark interest rate is also potentially devoted actively to promote economic growth. Therefore, the lessons learnt from Indonesia can be useful for other emerging countries to realize prices stabilization as well as to promote economic growth.

While some works directly assess the impact of central bank monetary policy communication on the policy interest rate, this study estimates it indirectly. First, we analyze the effect of central bank monetary policy communication on the inflation expectation gap. Second, we exam the contribution of the inflation expectation gap on the policy interest rate determination. The type of analysis presented in this paper has never been carried out by any other empirical study on central bank communication. To the best our knowledge, this is the first approach to evaluate dynamically whether the central bank monetary policy communication influences the direction of the policy interest rate. The rest of this paper is organized as follows. Section II presents a brief overview of the literature. Section III uses the press release of the Governor Board meetings to examine the impact of monetary policy and central bank communications on the price expectation formation as well as the policy interest rate decisions. This is followed by discussing the empirical results. The last section presents some of the concluding remarks and policy implications.

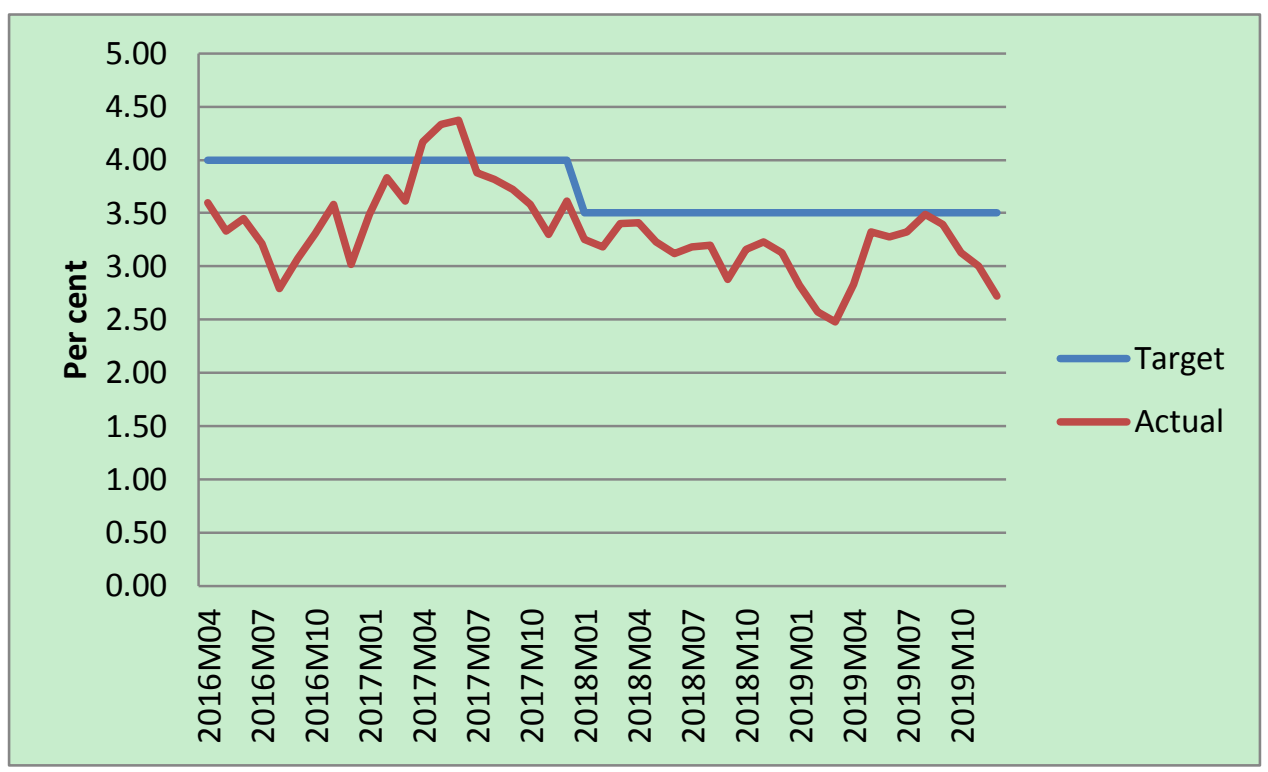

Figure 1. Indonesia's inflation rates (y-o-y)

Source: Bank Indonesia 


\section{Literature Review}

The literature on central bank communication in the inflation-targeting policy generally can be classified into two categories. The first category is estimating the effect of central bank communication on the market interest rates. This approach assumes that the interest rate pass-through is complete. The market interest rates are representative to the inflation expectation and fully adjust to the change in the policy interest rate. The second one is estimating the effect of central bank communication directly on the expected inflation rates. The latter assumes that the expected inflation and the actual inflation rates are incomplete. The inflation expectation does not fully adjust to the change in the actual inflation rates and, therefore, the policy interest rate in Taylor's rule covers the actual inflation rates instead of the expected inflation or targeted inflation rates.

In the first group, Kuttner and Posen (1999) analyzed the link between inflation expectations and inflation-targeting coupled with more communication in the UK, New Zealand and Canada. For the U.K., the results are in line with a successful policy of managing inflation expectations in check without omitting flexibility. The results for Canada are inconclusive, i.e. there is no single evidence on how the monetary policy reach the inflation target. Nevertheless, the analysis does not rely on direct measures of inflation expectations but rather employs indirect approaches such as Taylor's rule and the time-series properties of inflation rates.

Kliesen and Schmid (2004) investigated the influence of surprises in macroeconomic data releases, i.e. monetary policy surprises and central bank communication of the Federal Reserve, on the inflation expectations. They found that surprises in monetary policy actions bear on the two measures of inflation expectations. Further, the first measure indicates that the surprises in monetary policy actions increase uncertainty about the path the rate of inflation is going to take. Meanwhile, the second measure indicates that the Federal Reserve communication lowers uncertainty about the future inflation rate. Overall, they present that surprises in macroeconomic data issuances matter. The surprise components in data releases bear most severely on the behaviours of inflation expectations.

The different results above suggest communication, when it was priced in the market, can reduce the uncertainty of future inflation rates. Accordingly, the economic prospects conveyed by the central bank need special attention. Communication over the possibility of changes in policy interest rates in the future helps the central bank manage market expectations (Kahn, 2007). The clearly-stated numerical policy targets have small marginal effects, while the future direction that pays particular attention to future policy-level pathways has a large impact on the market (Pincheira and Calani, 2009; Hallett and Acocella, 2012; Bascand, 2013).

Future policy-level pathways are closely related to consistency. Examining the consistency of ECB communication, Jansen and De Haan (2009) concluded that ECB decisions are most closely associated with changes in forward-looking inflation expectations and economic sentiment. Communication offers an additional help in building the model of target rate decisions, but it does not undertake in the estimation of the target rate. Hayo and Neuenkirch (2010) studied that communication in the Federal Reserve had a more meaningful role in estimating target rate decisions confronted with Jansen and De Haan (2009). Their results suggest that the more informal part of the Federal Reserve communication contain useful information about monetary policy changes in the future.

While Jansen and De Haan (2009) and Hayo and Neuenkirch (2010) did not take into account the textual aspects, Apel and Grimaldi (2012) assessed them in the released minutes of the Riksbank's monetary policy meetings. They found a text-based measure of net hawkishness from each minute and obtained that increases in the interest rate in Sweden were related to a high degree of net hawkishness in Riksbank's communication. Cardaz (2012) in Brazil found evidence that economic agents consider the minutes of the Monetary Policy Committee meetings. Hence, the central bank communications remarkably affect the process of shaping expectations for each maturity of interest rates.

The similar result is earned by Herrero et al. (2017). They showed that the fluctuation in interest rate futures in Chile's swap markets escalates following the Central Bank's communication. However, the effect tends to be impermanent short-lived instead of persistent and statistically significant only in the pre-crisis period. Overall, their work exhibits a deminished relevance of Central Bank's communication for short-term swap markets that may represent the market players have learned to foresee changes in monetary policy communication, primarily in the post-global financial crisis.

Zhou and $\mathrm{Wu}$ (2016) studied the effect of central bank communication as a new monetary policy device to benchmark money market rates. Their finding shows the impact of central bank communication to the Shanghai Interbank Offered Rate (SHIBOR) is significant, the direction of influence follows the goal of monetary policy purposes; verbal communication is more cinsiderable than written communication in influencing the SHIBOR; 
improving the central bank of communication can mitigate short-term interest rate instabilities and can act as a conducive tasking in the financial markets.

Seelajaroen et al. (2019) produced evidence that monetary policy transparency and communication policy of the Bank of England have information content in reducing disagreement about interest rate forecasts. Interestingly, disagreement among the Monetary Policy Committee in policy rate decisions is associated with lower disagreement among professional forecasters on interest rate outlook, whereas neither announcement of changes in policy rates nor publication of inflation reports affects forecast disagreement. These results have important implications for monetary policymakers in managing market players expectations of interest rates.

In a broader coverage, Martin (2020) observed central banks inflation and found that expectations are well anchored for almost all economic players. The only segment whose inflation expectations diverge from the official inflation target and actual inflation is consumers. They suffer limited information so that cannot accurately assess the macroeconomic developments in general, and inflation trends in particular. However, the anchor of inflation expectations leads to the credibility of the monetary policy indicated by the absence of major inflationary and disinflationary pressures.

In the second group, Eusepi and Preston (2010), using a fully specified new Keynesian model, studied the role of central bank communication in the stabilisation of agents' expectations. They found that the Taylor rule in itself is inadequate to pursue macroeconomic stability without effective monetary policy communication. The Taylor rule works at anchoring market expectations only when the central bank's communication provides the detailed monetary policy. In contrast, Huang (2007) noted that in an uncertain environment, complete public disclosure by central banks may alleviate the impacts of bounded rationality.

Sturm and De Haan (2011) found that the text-based indicators taken from the ECB monetary policy reports were helpful for predicting the ECB future policy decisions. Luangaram and Sethapramote (2016) equipped the standard Taylor rule specifications with text-based measures extracted from the Bank of Thailand's monetary policy documents. They conclude the computed measures restored the performance of the Taylor rule models in forecasting future policy interest rate. A rise in policy interest rate can anchor expected inflation only in the short-term, whereas monetary policy communication offers additional effects to long-term inflation expectations.

Bold and Harris (2018) investigated whether Taylor's rule precisely explains the South African Central Bank's reaction function in determining interest rates. Their findings indicate that the South African Central Bank's policy rate decisions react to expected inflation (instead of current inflation), and its relationship to real economy fluctuations is evident in measures of labour market conditions rather than output gap variables. They concluded that South Africa's monetary policy has had a forward-looking inflation target that is conducted flexibly considering the labour market conditions.

The monetary policy reaction function for Sri Lanka was also done by Mayandy (2019). She indicates that the Central Bank of Sri Lanka followed the Taylor rule to set interest rates. Her forward-looking model estimations show that the coefficient on inflation increases over time, reflecting the greater focus on price stability. Zaheer et al. (2019) investigated the impact of monetary policy communication of the State Bank of Pakistan (SBP). The results show that the communication of monetary policy decisions changes the market sentiments following the information provided in the Monetary Policy Statement. Those findings support the effectiveness of SBP's monetary policy communication in guiding the market about the future path of interest rates.

Lee et al. (2019) quantified the Monetary Policy Board minutes of the Bank of Korea (BOK) using text mining. They found that Korean lexicon-based measures help predicting the future BOK monetary policy decisions when taking into account an augmented Taylor rule, advocating that they enrich information beyond the currently available macroeconomic variables. Their indicators are much better than English-based textual classifications, a media-based measure of economic policy uncertainty, and a data-based measure of macroeconomic uncertainty. Their empirical findings also point out the importance of using a field-specific dictionary and the original Korean text.

Regarding the literature on central bank communication in Indonesia, this is still incipient. Anwar and Chawwa (2008) observed the behaviour of inflation expectations in the Indonesian goods and money markets before and after the adoption of the inflation-targeting regime. They found the price expectations in the money market are closer to the actual values than that in the goods market. Their survey indicated that market perception is better reflected in the inflation target range than the actual inflation. Another interesting finding is that the application of the inflation-targeting policy has directed the economic agents' inflation expectations follow the established inflation target. 
While Anwar and Chawwa (2008) concerned about the inflation expectations in money market without analyzing central bank communication, Sahminan (2008) reviewed the signalling effect through the official announcement of the central bank's monetary policy. His empirical results show that to some extent the announcement of the monetary policies of the Central Bank of Indonesia can move short-term interest rates effectively. He also found that there is an asymmetric effect. Statements with loose policy tendencies tend to be more effective compared to statements with strict policy tendencies. Unfortunately, his research only links the clarity of the central bank's statement with banking interest rates, rather than inflation expectation or policy interest rate.

Dewati et al. (2009) concluded that the central bank communication strategy has a significant influence in determining the gap between inflation expectation and actual inflation. Every increase of one wording indicator unit will reduce the inflation expectation gap. An increase in the value of the wording indicator shows that information held by the central bank is getting closer to the information held by the public forming each other's expectation so that actual inflation will be closer to inflation expectations. However, given the scope of their study is limited to price expectations only, the results cannot be generalized to determine the policy interest rates.

Kuncoro (2015) confronted the backward- and forward-looking approaches of the policy interest rate determination. Using the central bank policy reaction function, he found that the result of the forward-looking approach is better. The central bank takes into account the future inflation rate to target rate gap relative to the current gap of the inflation rate. Further, there is a long-run effect of output growth on the policy interest rate represented by the significance of the lagged output. It means that the central bank indirectly has responsibility for output growth as an extra task in the long-run. Unfortunately, Kuncoro (2015) did not involve text-mining in his analysis.

Based on the above previous studies, two caveats emerge. First, the existing literature provides diverging results that central bank monetary policy communication influences the formation of inflation expectations as well as interest rates. However, an area which has not been explored in the empirical literature is the link between inflation expectations and actual inflation. Two, the large literatures above also suggest that there is no unique conclusion of about how central bank communication affects the inflation expectation gap. If any, the size of the effect has not gained yet a general consensus. The estimation results of the impact of inflation expectation gap on the interest rate primarily in the emerging countries are also debateable due to different time frame, method, and monetary regime. Those bring us to synthesize the two issues into an integrated model.

\section{Research Method}

This study departs from a question of whether the central bank communication and the clarity of announcements about the monetary policy (i.e. the quality of information) influence the formation of inflation expectations so that inflation expectations are the same as actual inflation. The narrower gap between inflation expectations and actual inflation will make the central bank more easily to determine the benchmark interest rate as the major instrument in the inflation-targeting frameworks.

In our view, the central bank monetary policy communication shapes the public inflation expectations rather than directly affect the policy interest rate. Therefore, we estimate first the influence of the central bank monetary policy communication on the inflation expectations compared to the actual inflation. Then, we identify the effect on the estimated inflation expectations gap on the benchmark interest rate. In the econometric point of view, the introduction of estimated inflation expectations gap is to control potential endogeneity problems, particularly arising from interest rate and monetary policy communication.

Furthermore, the literature on communication clarity focuses its analysis on the readability aspect. This is because most of the communication is made in a written release. Therefore, legibility is an important part of this framework. Clarity relates to the clarity and legibility of texts (Jansen, 2011a and 2011b; Bulír et al., 2013; Montes et al., 2016; Jansen and Moessner, 2016; Mendonca and Nicolay, 2017; Montes and Nicolay, 2017). If someone has to process text with long words or sentences, it will be more difficult to understand the message (Jansen, 2011b).

The first dimension of the complexity of a text concerns the number of words used. Longer statements are cognitively burdening the reader. It is equally important to take into account the grammar and structure of the statement. For this purpose, clarity of announcement must be able to measure the readability and lexical diversity of the statement. In this case, the Flesch ease score (Flesch, 1948) is a suitable proxy to indicate the clarity of the announcement.

Flesch's Statistics (1948) allows textual aspects, as the amount of words per sentence and the quantity of syllables per word. The Flesch Index (FI) shows the ease of reading text. Scores range from 0 to 100. A score of 100 indicates easy to understand a text, a score of 70 indicates easy to understand text for adults, a score of 30 indicates very 
difficult to understand the text. Kincaid et al. (1975), derived from Flesch, modified a formula which calculated it into a level $(G L)$ to evaluate a text.

$$
G L=0.39 \times \frac{\# \text { Words }}{\# \text { Sentences }}+11.8 \times \frac{\# \text { Syllables }}{\# \text { Words }}-15.59
$$

$G L$ values indicate direct clarity. If $G L$ increases, it represents higher clarity in communication. $G L$ at level six, for example, fits for someone under formal education who is 11-12 years old. The $G L$ index is the most widely readable readings indicator used in the literature on central bank monetary policy communication (see for example Luangaram and Wongwachara, 2017).

The second aspect concerns content. The contents of the release of the results of the board of governors' meeting are classified into an index that uses a discrete and positive scale. The contents of the announcement giving clarity of the policy direction for the future are given a score of 1 (one). A score of 0 (zero) is given for 'flat' announcement content without informing the policy direction going forward. Therefore, this index is a dummy binary variable, Tone, about the tone of monetary policy.

$$
\log (P E)_{t}=\alpha+\beta G L_{t}+\gamma \text { Tone }+\omega_{t}
$$

Furthermore, the actual prices level $(P A)$ is assumed to be performed following the autoregressive process:

$$
\log (P A)_{t}=(1-\lambda) \log (P A)_{t-1}+\epsilon_{t}
$$

Combining (2) and (3) yields the prices level gap between the expected prices and the actual prices:

$$
\log \left(\frac{P A}{P E}\right)_{t}=\alpha+\beta G L_{t}+\gamma \operatorname{TONE}+(1-\lambda) \log (P A)_{t-1}+\varepsilon_{t}
$$

The inflation rate is understood to be a relative increase in the general price index. The expected inflation refers to the expected price index, while the actual inflation refers to the actual price index.

$$
\begin{gathered}
\operatorname{Inf} f^{a}=\frac{P A_{t}-P A_{t-1}}{P A_{t-1}} \approx \log (P A)_{t}-\log (P A)_{t-1}=\Delta \log (P A)_{t} \\
\operatorname{Inf}^{e}=\frac{P E_{t}-P E_{t-1}}{P E_{t-1}} \approx \log (P E)_{t}-\log (P E)_{t-1}=\Delta \log (P E)_{t}
\end{gathered}
$$

The inflation expectation gap is measured as the difference between the actual inflation and the expected inflation.

$$
\begin{aligned}
I G_{t} & =\left(I n f^{a}-\operatorname{Inf}^{e}\right)_{t} \\
& =\Delta \log (P A)_{t}-\Delta \log (P E)_{t}=\Delta \log \left(\frac{P A}{P E}\right)_{t}
\end{aligned}
$$

The perception of economic actors towards economic development including inflation rates tends to change over time. To accommodate them, the econometric approach for estimating (4) uses the Autoregressive Distributed Lags (ARDL) method. Remembering that the results of standard unit-root tests might be inconclusive, Pesaran and Shin (1999) proposed that ARDL models produce consistent estimates of the coefficients regardless the underlying regressors are integrated into degree one $(I(1))$ or degree zero $(I(0))$, thus ensuring robustness to the results. The ARDL model takes the restricted form as follows:

$$
\begin{aligned}
\widehat{I G}_{t}=\Delta \log \left(\frac{P A}{P E}\right)_{t}=\alpha & +\beta_{1} \Delta G L_{t}+\beta_{2} G L_{t-1}+\gamma_{1} \Delta \text { Tone }_{t} \\
& +\gamma_{2} \text { Tone }_{t-1}+\lambda_{1} \Delta \log (P A)_{t} \\
& +\lambda_{2} \log (P A)_{t-1}+\phi \log \left(\frac{P A}{P E}\right)_{t-1}+\varepsilon_{t}
\end{aligned}
$$

where $\phi$ is coefficient of partial adjustment, $0 \leq \phi \leq 1$.

The Wald test is calculated to verify the null hypothesis, $\mathrm{H}_{0}: \beta_{2}=\gamma_{2}=\lambda_{2}=\phi=0$ against the alternative hypothesis, $\mathrm{H}_{\mathrm{a}}$ : $\beta_{2} \neq \gamma_{2} \neq \lambda_{2} \neq \phi \neq 0$. When the Wald test value lies outside the tolerated interval bound, the null hypothesis of no cointegration cannot be accepted. In contrast, if the Wald test value stands inside the tolerated interval bound, the null hypothesis of no co-integration is accepted. In other words, series data of $P E, P A$, and $F I$ are claimed to be co-integrated. 
The inflation gap will determine the policy interest rate as an anchor for inflation-targeting policies. Following Taylor's rule, when the actual inflation is higher than the expected inflation, the central bank will raise the benchmark interest rate. Conversely, when the actual inflation is lower than the expected inflation, the central bank will lower the benchmark interest rate. The Taylor rule (1999) was tested for the following regression equation:

$$
\Delta i r_{t}=a+b \widehat{I G}_{t}+c\left(y_{t}-y_{t}^{*}\right)+d\left(e r_{t}-e r_{t}^{*}\right)+e \Delta i r_{t-1}+\mu_{t}
$$

The output ( $y$ in a logarithmic form) gap and inflation expectation gap are the main variables in the Taylor model. An additional variable is necessary to represent the stabilizing force of the monetary authority. Therefore, the third variable in the model is the exchange rate ( $e r$ in a logarithmic form), which is the value of foreign currency in term of domestic currency. We also include the past interest rate decision change $\left(\Delta i r_{t-1}\right)$ in the benchmark model. The latter variable is used to accomodate the interest rate smoothing pattern (Kuttner, 2004). The past interest rate change is advocated by Goodhart and Lim (2011) as the predictor of the future policy interest rate change. When the change in interest rate remains at a low level, the probability of interest rate change will be converse to the long-run average value should not be increased, and vice versa. After adding the third variable, the lagged variable change, and the latent variable, the complete Taylor rule were ready to refect the changes in the policy interest rate.

The coefficient of $b$ shows the response of the policy nominal interest rate to a rise in inflation expectation gap. If $b<$ 1 , the increase in the policy interest rate would never restrain to neutralize the increase in inflation expectation gap so that the real policy interest rate would decrease instead of increasing. Therefore, the monetary authority will not at all govern to squeeze the excess demand that caused inflation expectation gap to rise out of the economy so that the targeted inflation rate will rarely be reached. In this case, the Taylor rule would be unreliable and would not act as a nominal anchor for central bank.

This study used data mostly from the Central Bank of Indonesia. The text of the press release of the Board of Governors' Meeting results will be reviewed for the clarity as well as readability. The text was obtained from official documents from the Department of Communication of Central Bank of Indonesia. We explore the Monthly Report in Indonesian, even though the official English translation is also provided at the Bank of Indonesia's website. This is unavoidable since the Governor Board of the Central Bank of Indonesia uses Indonesian for their internal discussions, decision making, and announcement to the public. Therefore, economic agents react to the Indonesian version.

Data on inflation expectations were also obtained from a survey held by the Central Bank of Indonesia. The Central Bank of Indonesia conducts a routine monthly survey of a sample of all economic actors to determine the future inflation forecasts. The inflation expectationis specified into inflation 3-month-ahead. The Central Bank of Indonesia's survey result is presented in the form of an index. According to the data survey, an index of 100 shows a stable forecast of prices over the next three months. An index below 100 indicates the expectation of falling prices, while an index above 100 indicates the expectation of price increases. Although the data survey is not always accurate as a predictor of inflation expectation, they remain to present valuable information about short-term inflationary pressures (Anwar and Chawwa, 2008). Moreover, in explaining inflation dynamics, the use of survey-based data are relatively superior over model-based ones or expectations derived from financial market instruments (Szafranek, 2017).

The actual price index was taken from the Central Agency of Statistics. The consumer price index is calculated for 1 month as a reference to the prices level expectations. Due to unavailability of monthly-GDP data, the output is represented by the industrial production index. We define output gap as the actual output growth; the difference between the current output and the previous one by assuming that the latter is the potential output. The exchange rate is the price of the US Dollar against Rupiah stated in the mid-value. The scope of this research extends from April 2016 to December 2019. The April 2016 period is set as the beginning of observation related to the use of 7-day reverse repo rates (1-week tenor) as policy rates replacing the BI rate (12 months tenor). The total sample of this study includes 45 -time series points. Eviews econometric software package is used to execute the empirical models as specified above.

\section{Results and Discussion}

Table 1 provides the descriptive statistics covering mean, median, and extreme (maximum and minimum) values for each variable of interest. The average values of the month-to-month actual $\left(I n f^{a}\right)$ and expected inflation $\left(\operatorname{Inf}^{e}\right)$ rates, and therefore the inflation expectation gap, are relatively low. However, the expected inflation rate is more volatile compared to the actual inflation rate as presented by the higher standard deviation referred to the respective mean value. Applying a one-sample test proves that the mean value of Inf ${ }^{a}$ significantly does not exceed from Inf at the 5 per cent confidence level. Accordingly, it implies that the movement of inflation expectation gap does not 
considerably vary. As a result, the difference between inflation expectations toward actual inflation rather than inflation targets narrows. In other words, the actual inflation is representative of the inflation target.

The average value of the GL is 21.7. It seems that the text of monetary policy announcements is very difficult to read. In the US education system, the 22-scored readability text is best understood by university graduates. The result is reasonable when we look at the tone. The number of contents of the announcement giving clarity of the policy direction for the future is less than that of 'flat' announcement content without informing the policy direction going forward. These raise a preliminary hypothesis whether the low inflation expectation gap is associated with the lack of policy direction going forward or the expected inflation rate refers solely on the actual inflation rate, i.e. public expectation is independent to the monetary policy announcement.

The average values of policy interest rate, output, and exchange rate are not far enough from their each median values. They perform that the variables are normally distributed, consistent with the low skewness. The Jarque-Bera normality tests confirm that the three variables have bell-shaped distributions. However, the variability of the policy interest rate is relatively higher. This conclusion is drawn by looking at the coefficient of variation (standard deviation to mean ratio). The coefficient of variation for the relative change in the policy interest rate is the highest 12 per cent among the three variables. Accordingly, the change in policy interest rate seems to be unable to anchor the inflation expectation gap. It will be check again more deeply using econometric models.

Table 1. Descriptive statistics

\begin{tabular}{|c|c|c|c|c|c|c|c|}
\hline & $\operatorname{Inf}^{a}$ & $\operatorname{Inf} \mathrm{e}^{\mathrm{e}}$ & GL & TONE & IR & $\log (\mathrm{Y})$ & $\log (\mathrm{ER})$ \\
\hline Mean & 0.0028 & 0.0001 & 21.6944 & 0.3182 & 5.0909 & 4.9460 & 9.5317 \\
\hline Median & 0.0023 & 0.0044 & 21.6257 & 0.0000 & 5.0000 & 4.9459 & 9.5257 \\
\hline Maximum & 0.0097 & 0.1101 & 22.5846 & 1.0000 & 6.0000 & 5.0626 & 9.6308 \\
\hline Minimum & -0.0027 & -0.0908 & 20.7329 & 0.0000 & 4.2500 & 4.8298 & 9.4726 \\
\hline Std. Dev. & 0.0027 & 0.0396 & 0.4705 & 0.4712 & 0.6078 & 0.0562 & 0.0379 \\
\hline Skewness & 0.3719 & -0.1424 & -0.0393 & 0.7807 & 0.1778 & -0.0246 & 0.5114 \\
\hline Kurtosis & 2.6430 & 3.7995 & 2.1900 & 1.6095 & 1.8113 & 2.1371 & 2.5541 \\
\hline Jarque-Bera & 1.2482 & 1.3206 & 1.2141 & 8.0145 & 2.8224 & 1.4008 & 2.3342 \\
\hline Probability & 0.5358 & 0.5167 & 0.5450 & 0.0182 & 0.2439 & 0.4964 & 0.3113 \\
\hline
\end{tabular}

In line with some previous research findings, a potential empirical issue arises is the possibility of a causal relationship between the two variables. To avoid this risk, Granger's causality test will be conducted first to ascertain whether the expected inflation affects the actual inflation or the actual inflation influences the expected inflation. The granger causality test is conducted twice for 3 and 4 lags respectively. The chosen lags are based on the Akaike, Schwarz, and Hannan-Quinn criterion.

The results of Granger causality test are presented in Table 2. Both lags of actual inflation Granger cause any of the expected inflation variables at the 5 and 10 per cent confidence levels respectively. Conversely, both lags of expected inflation do not Granger cause any of the actual inflation variables. This means a unidirectional causality runs from actual inflation towards expected inflation. Put simply, we may construct that the expected inflation is a function of actual inflation. It implies that information of the actual inflation in the pasts periods can be utilized to predict the current value of the expected inflation.

The same procedures are applied to the policy interest rate and inflation expectation gap. Both lags of inflation expectation gap Granger cause any of the interest rate variables at the 5 and 10 per cent confidence levels respectively. Conversely, both lags of inflation expectation gap do not Granger cause any of the policy interest rate variables. Based on those results, we may construct that the inflation expectation gap is a function of the policy interest rate. It implies that information of the inflation expectation gap in the pasts periods can be utilized to predict the current value of the policy interest rate. 
Table 2. Granger Causality Tests

\begin{tabular}{|c|c|c|c|c|}
\hline Null Hypothesis: & Obs & F-Stat & Prob. & Conclusion \\
\hline INF $^{\text {a }}$ does not Granger Cause INF & \multirow{2}{*}{41} & 4.5636 & 0.0086 & \multirow{4}{*}{$\mathrm{INF}^{\mathrm{e}}=\mathrm{f}\left(\mathrm{INF}^{\mathrm{a}}\right)$} \\
\hline INF $^{\mathrm{e}}$ does not Granger Cause INF ${ }^{\mathrm{a}}$ & & 0.3603 & 0.7820 & \\
\hline INF $^{\text {a }}$ does not Granger Cause INF ${ }^{e}$ & \multirow{2}{*}{42} & 8.8391 & 0.0007 & \\
\hline INF $^{\mathrm{e}}$ does not Granger Cause INF ${ }^{\mathrm{a}}$ & & 0.2325 & 0.7937 & \\
\hline IG does not Granger Cause IR & \multirow{2}{*}{40} & 2.6911 & 0.0616 & \multirow{4}{*}{$(\mathrm{IR})=\mathrm{f}(\mathrm{IG})$} \\
\hline IR does not Granger Cause IG & & 2.0328 & 0.1277 & \\
\hline IG does not Granger Cause IR & \multirow{2}{*}{41} & 3.3216 & 0.0224 & \\
\hline IR does not Granger Cause IG & & 1.9937 & 0.1200 & \\
\hline
\end{tabular}

To test our hypothesis, we run the ARDL model as outlined in equation (7). The estimation results as performed in Table 3 reveal the coefficients of lagged regressands are statistically significant. Also, the coefficients of the lagged regressors are significant. These preliminary indicate the existence of co-integration. To make sure the appearance of co-integration, we verify the possibility of co-integration by carrying out the bound test. As presented in Table 4, the values of the Wald test fall outside the upper tolerated bound at the 5 and 10 per cent significance levels. The null hypothesis of no co-integration could be rejected, implying the existence of co-integration among the inflation expectation gap, text readability, and the actual inflation rate.

Alternatively, employing maximum likelihood approach as developed by Johansen (1988; 1991), we verify the bi-variate among the three variables. The trace statistics along with the maximum eigenvalue ( $\lambda$ max $)$ to examine the rank of co-integration are presented in Table 5. The results are in line with the bound tests. Test for Taylor's rule regression equation also performs cointegration. Hence, the tests perform the existence of the co-integrating equations among the non-stationary series. It means the linear combinations of those variables (even stationary at the different levels) are stationary and the long-run relationship inclines towards the equilibrium.

Table 3. Estimation result of inflation expectation gap

\begin{tabular}{lcc}
\hline Dep. Var: IG & Coeff. & Prob. \\
\hline $\mathrm{C}$ & -1.9780 & 0.0236 \\
\hline$\Delta$ GL & 0.0049 & 0.0822 \\
\hline GL(-1) & 0.0074 & 0.0520 \\
\hline$\Delta$ Tone & -0.0213 & 0.0806 \\
\hline Tone(-1) & -0.0366 & 0.0834 \\
\hline$\Delta$ Log PA & 6.4741 & 0.0014 \\
\hline Log PA(-1) & 0.4215 & 0.0221 \\
\hline LAGGED & -0.4452 & 0.0005 \\
\hline $\mathrm{R}^{2}$ & 0.4827 & \\
\hline Adj-R & & \\
\hline SEE & 0.3821 & 0.0007 \\
\hline F & 0.0320 & \\
\hline DW & 4.7984 & \\
\hline
\end{tabular}

Diagnostic tests can be obtained from the author upon request 
Table 4. Wald Cointegration Tests

\begin{tabular}{lrrr}
\hline Wald Test: & \multicolumn{1}{c}{ Value } & df & Probability \\
\hline F-statistic & 4.3905 & $(4,36)$ & 0.0054 \\
\hline Chi-square & 17.5621 & 4 & 0.0015 \\
\hline
\end{tabular}

Table 5. Johanson's Cointegration Tests

\begin{tabular}{|c|c|c|c|c|}
\hline \multicolumn{5}{|l|}{ Hypothesized } \\
\hline No. of CE(s) & Eigenvalue & Statistic & Critical Value & Prob. \\
\hline \multicolumn{5}{|l|}{ Eq. (7) } \\
\hline None * & 0.3687 & 35.7439 & 29.7971 & 0.0092 \\
\hline At most $1 *$ & 0.2886 & 15.9618 & 15.4947 & 0.0425 \\
\hline At most 2 & 0.0302 & 1.3166 & 3.8415 & 0.2512 \\
\hline \multicolumn{5}{|l|}{ Eq. (8) } \\
\hline None * & 0.6818 & 87.4021 & 47.8561 & 0.0000 \\
\hline At most $1 *$ & 0.5120 & 39.3033 & 29.7971 & 0.0030 \\
\hline At most $2 * *$ & 0.0852 & 3.7392 & 3.8415 & 0.0531 \\
\hline At most 3 & 0.1213 & 9.1683 & 15.4947 & 0.3501 \\
\hline
\end{tabular}

Note: $*$ and $* *$ presents the level of significance at 5 and 10 percent respectively

In the short-run, the clarity of text announcement $(G L)$ has only a marginal effect to reduce the 3-month-ahead inflation expectation gap. Even, the tone variable in the short-run is significant at the 90 per cent confidence level. They imply that market players relatively do not consider the quality of information content delivered in the central bank announcement to perform their 3-month-ahead inflation expectation. Conversely, the market players pay more attention to the actual inflation rate. The much higher impact of the actual inflation rate denies the effect of the clarity and tone on the 3-month-ahead inflation expectation. This result confirms to Kuttner and Posen (1999) and Kliesen and Schmid (2004) regarding the release of macroeconomic data and Sahminan (2008) in the context of the policy interest rate announcement.

However, the result is quite different when we consider the long-term perspective. The impact of the quality of announcement on the 3-month-ahead inflation expectation gap as presented in the lagged dependent variable becomes more significant. In other words, the market players respond to the change in information contents. In this case, they would decrease their inflation expectation irrespective to the actual inflation rate. It means that the degree of backwards-looking behaviour (as found by Dewati et al. (2009)) gradually declines. In the international context, those findings confirm to Hayo and Neuenkirch (2010) for ECB and Martin (2020) in the case of Serbia respectively.

The above results imply that the market players could be risk aversive, trusting the central bank announcement in the longer time horizon. Accordingly, they prefer to believe that the central bank will commit to the inflation target rather than the actual inflation rate as found by Anwar and Chawwa (2008). The above results are plausible. The targeted inflation rate in Indonesia is set for a year-ahead - instead of a month-ahead or three-month-ahead - and applies for three years in advanced. Therefore, the market players consider the signal of monetary policy is credible as found by Apel and Grimaldi (2012).

The central bank commitment to the targeted inflation rate is also justified. In the long-run, the lagged prices level determines the inflation expectation so that the inflation expectation gap would decline. The coefficient of lagged $\log (P A)$ is found to be negative and statistically significant at the 95 per cent confidence level for both models. In this case, the capability of a central bank to preserve the actual price levels is critical in stabilizing prices fluctuation in the long-run. It also is notable that prices stabilization in the future requires prices stabilization in the current period to maintain the credible monetary policy as found by Montes and Nicolay (2017). This finding is also consistent with Luangaram and Sethapramote (2016) in the case of Thailand. 
The important findings above suggest improvements in transparency. The principles of accountability and transparency should consistently be implemented by way of delivering information related to policies to all of the stakeholders. The adoption of horizontal proactive and multi-channel requires active and two-way communication. To disseminate information on its policies and planned policies early, the Central Bank of Indonesia could use various available instruments following the public needs. Those strategies are eventually directed to support the achievement of the Central Bank of Indonesia goals. Under those circumstances, central bank communication can manage the public expectations that conform to the policy direction.

Furthermore, the coefficient of the lagged dependent variable is statistically significant. The corresponding coefficients display persistence. The inflation expectation gap persistence can be seen as a measure of the degree of dependence of current inflation expectation gap behaviour on its past developments. The coefficient of the lagged dependent variable is 0.4. It suggests that a change in the inflation expectation gap between the previous month and the current month induces the inflation expectation gap process in the current monthis only 0.4 percent adjusting to the desired level. Consequently, the inflation expectation gap in the short-run tends to be less persistent than the response of the change in prices level.

Eventually, tying up inflation expectations to inflation targets instead of actual inflation hints a credible monetary policy. Our questions in mind are: Does the monetary policy become less credible when the actual inflation rate is lower than the targeted inflation rate? Does the monetary policy become more credible when the expected inflation rate is lower than the targeted inflation rate? In the case of Indonesia when the targeted inflation rate was predetermined for 3 years in advance, we cannot evaluate the credibility. To avoid those problems, we combine the actual inflation rate and the expected inflation rate, instead of the targeted inflation rate. The inflation expectation gap is representative to analyze the policy interest rate.

The coefficient of $\widehat{I G}_{t}$ represents the reaction of the nominal policy interest rate to a rise of the inflation expectation gap. The corresponding coefficient is found to be positive (1.7 and 1.5) significantly greater than unity at 5 per cent or at least 10 per cent confidence levels both in the most basic form (Model 1) and Model 2. The increase in the policy interest rate would always manage to compensate the increase in inflation so that the real policy interest rate would rise instead of falling. The central bank will therefore always control the demand shortage that caused deflation to revive the economy so that the targeted inflation rate will be achieved.

In such a case, the Taylor rule would be stable and acts as a nominal anchor for monetary policy. This result confirms the brief visual inspection of Figure 1 at the beginning of this article. Given this, we can conclude that the monetary policy is credible in the sense that the official central bank's announcement provides the signalling effect for economic agents to make a decision. Consequently, public disclosure by central banks may not erode the impacts of bounded rationality as claimed by Huang (2007). The economic agents learn the public disclosure by monetary authorities to anticipate changes in monetary policy communication as inferred by Herrero et al. (2017).

Table 6. Estimation results of policy interest rate

\begin{tabular}{|c|c|c|c|c|c|c|c|c|}
\hline \multirow{2}{*}{$\begin{array}{l}\text { Dep. Var: } \\
\Delta \text { IR }\end{array}$} & \multicolumn{2}{|c|}{ (1) } & \multicolumn{2}{|c|}{ (2) } & \multicolumn{2}{|c|}{ (3) } & \multicolumn{2}{|c|}{ (4) } \\
\hline & Coeff. & Prob. & Coeff. & Prob. & Coeff. & Prob. & Coeff. & Prob. \\
\hline $\mathrm{C}$ & -0.0106 & 0.6356 & -0.0078 & 0.7136 & -0.0120 & 0.5885 & -0.0092 & 0.6646 \\
\hline$\widehat{I G_{t}}$ & 1.7681 & 0.0316 & 1.5052 & 0.0570 & 1.8755 & 0.0224 & 1.6125 & 0.0417 \\
\hline$\Delta \log Y$ & - & - & -0.8623 & 0.0336 & - & - & -0.8295 & 0.0394 \\
\hline$\Delta \log$ ER & - & - & - & - & 1.8055 & 0.1738 & 1.6338 & 0.1992 \\
\hline$\Delta \operatorname{IR}(-1)$ & 0.4440 & 0.0017 & 0.4460 & 0.0010 & 0.4216 & 0.0026 & 0.4257 & 0.0016 \\
\hline $\mathrm{R}^{2}$ & 0.3307 & & 0.4047 & & 0.3621 & & 0.4303 & \\
\hline Adj-R ${ }^{2}$ & 0.2972 & & 0.3589 & & 0.3130 & & 0.3703 & \\
\hline SEE & 0.1443 & & 0.1378 & & 0.1427 & & 0.1366 & \\
\hline F & 9.8810 & 0.0003 & 8.8379 & 0.0001 & 7.3785 & 0.0005 & 7.1755 & 0.0002 \\
\hline DW & 1.9381 & & 1.9140 & & 2.1207 & & 2.1132 & \\
\hline
\end{tabular}

Diagnostic tests can be obtained from the author upon request 
The coefficient output gap in Model 2, in contrast, is obtained to be negative and statistically significant. It means that the actual output is below the potential output. Since we used the lagged output as a measure of the potential output, the negative sign of output gap indicates the national output growth tends to decline. The use of Hodrick-Prescott filtered detrending method does not alter the result. It confirms the trend of domestic economic recession recorded during the last few years. However, the significant effect of output gap to policy interest rate means that the central bank indirectly has a responsibility for output growth as an additional duty in the long-run as found by Kuncoro (2015).

Regardless of the signs, the magnitude of $\widehat{I G}_{t}$ is greater than that of potential output. As a consequence, the policy interest rate set by the Central Bank of Indonesia is more sensitive to the change in inflation expectation gap rather than the output gap. Therefore, it is not surprising that the Central Bank of Indonesia has become so responsive in responding to any change in the inflation expectations. In such a case, the inflation target is relatively moderate and achievable compared to the actual inflation. However, the dominance of the backwards-looking mindset (as found in the previous analysis) is the main cause of why the Central Bank of Indonesia's policies has not been effective in influencing the formation of inflation expectations (Dewati et al., 2009). This result is contrasted with Lee et al. (2019) that the Bank of Korea is more sensitive to output gap rather than the change in inflation expectation gap. Different level and type of economy between Indonesia and Korea may the main causes.

When we include a variable related to the exchange rate in column (3) and (4), the coefficient of the output gap remains to be statistically significant. The same result holds for the coefficient of the inflation expectation gap. Indeed, the Central Bank of Indonesia never set the level of exchange rate target. The exchange rate gap is therefore measured as the relative change in exchange rate compared to the lagged. Similar to the output gap, the use of Hodrick-Prescott filtered detrending method does not change the result that the exchange rate gap does not affect the policy interest rate determination.

However, the Central Bank of Indonesia often intervenes to the foreign exchange market when the exchange rate is considered too 'high'. Based on those results, we infer that the inflation-targeting in Indonesia underlines more heavily the domestic currency stabilisation rather than the exchange rate stabilisation. Although the exchange rate volatility is relatively high, it seems that the exchange rate does not take away some of the explanatory power of inflation expectation gap and the output gap. The latter suggests that the results are consistent with those from standard textbooks and imply substantiation of the impossible trinity - that the three conditions of the floating exchange rate, monetary independence, and capital mobility, cannot exist simultaneously.

The coefficient of the lagged dependent variable is hypothesized to be in the range between 0 and 1 . The effect on interest rate smoothing is significant for all models specifications. This means there is asymmetric information so that the inflation expectations gap cannot be fully accommodated in the benchmark interest rate. Consequently, the movement of the policy interest rate is not fully represented by the previous period's benchmark interest rate. Thus, the future policy interest rate set by the central bank is not easy to predict. The marginal effects of the lagged variable show a decision to change the target rate inthe previous meeting increases the partial adjustment of a rate change on the average by 56 per cent.

Those results confirm significant interest rate inertia, despite changes in the conduct of monetary policy across different policy regimes. Our results are also consistent with the conventional wisdom that the central bank seeks smoothness by adjusting the interest rate. This implies that the Central Bank of Indonesia changes its policy rates gradually in response to macroeconomic developments. This result is in line with almost developing countries, for example, Bold and Harris (2018) for South Africa, Mayandy (2019) in the case of Sri Lanka, and Zaheer et al. (2019) in the case of Pakistan.

The evidence obtained so far suggests that the inflation expectation gap is influential in the process of policy interest rate setting. Since central bank monetary policy reflects some institutional aspects, we next re-examine to further confirm the absence of structural breaks.CUSUM (the cumulative sum) and CUSUMSQ (the cumulative sum square) as an alternative test of structural breaks are conducted for the first two models since they produce statistically good results. A sample CUSUM and CUSUMSQ structural break tests result is given in Figure 2.

The plots of the CUSUM and CUSUMSQ tests for Model 1 in Figure 2 fall within the 95 per cent confidence bands, which demonstrate the stability of estimated parameters. The plots of the CUSUMSQ particularly for Model 1 in the beginning observations precisely at the 95 per cent confidence bands. However, the overall estimated parameter in the model is stable. Those results present the successful effect of central bank monetary policy communication on the inflation expectation gaps in Indonesia and therefore the impact of inflation expectation gaps on policy interest rate is 
stable. Our findings also support the point made in Lucca and Trebbi (2011). The quality of the central bank announcement should not be omitted when identifying monetary policy shocks in the standard monetary models.

\section{Model 1}
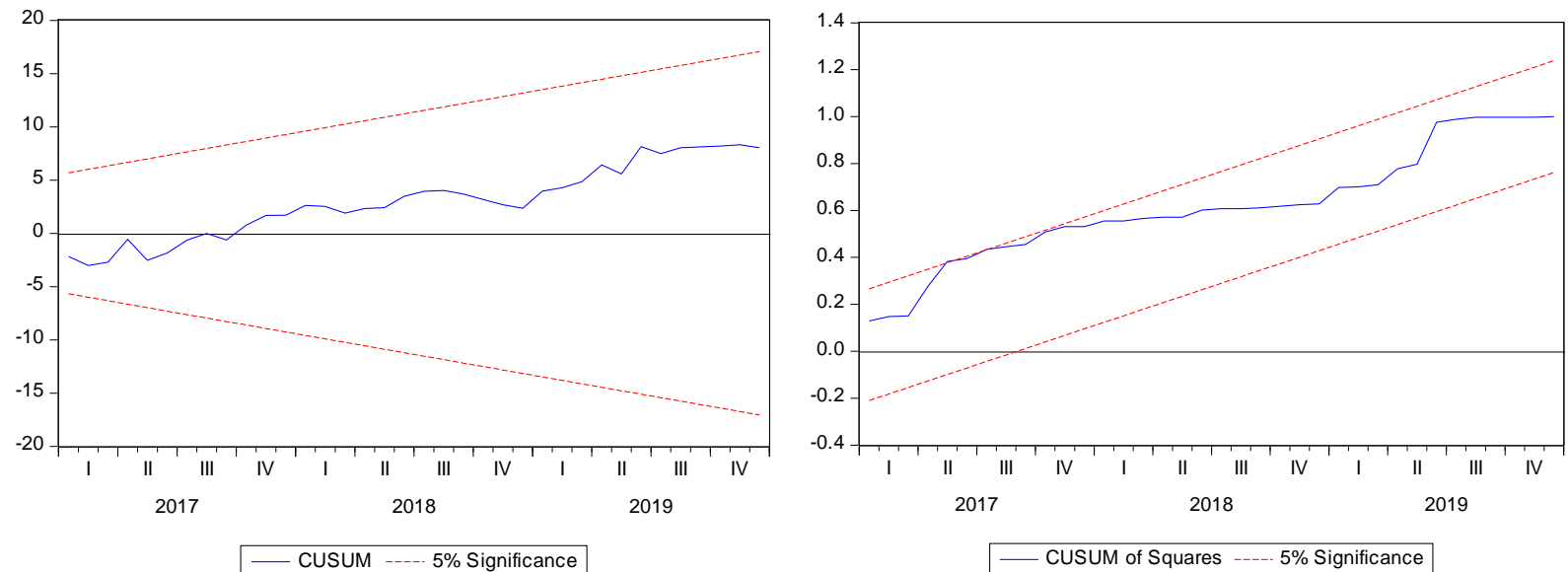

Model 2
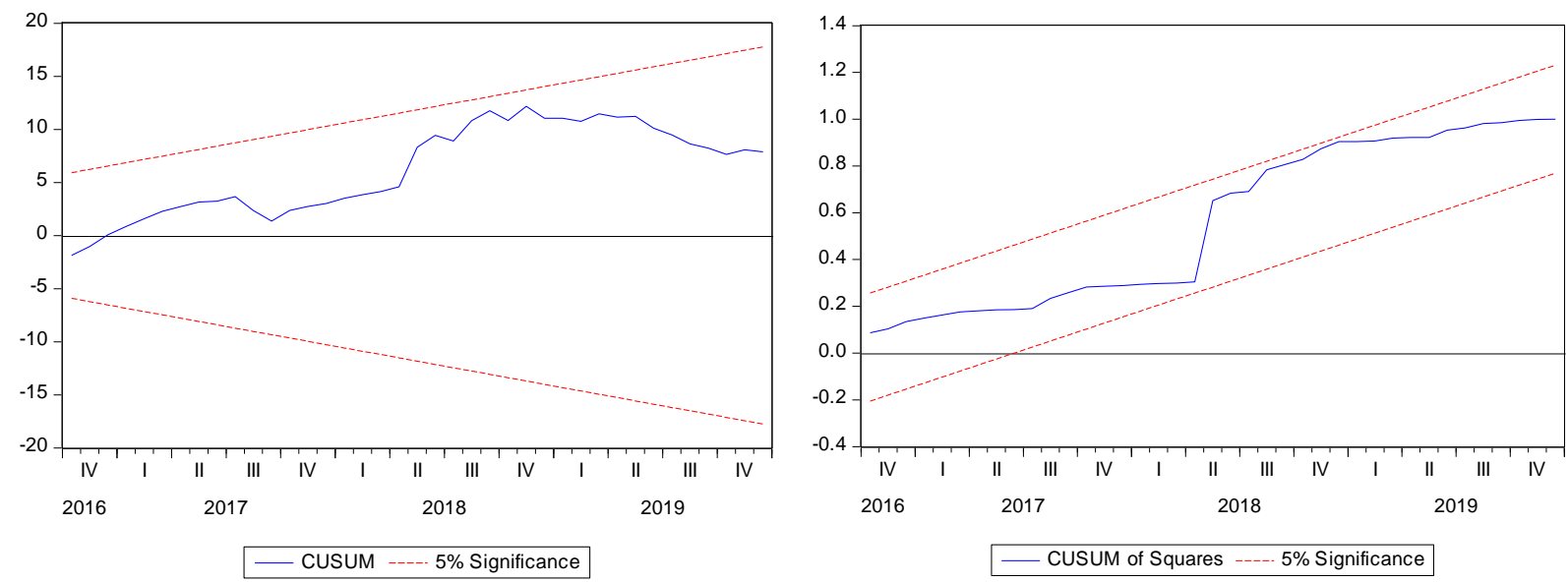

Figure 2. CUSUM and CUSUMSQ Tests

\section{Concluding Remarks}

Central bank communications play an important role to guide inflation expectations. For emerging economies, especially for Indonesia, however, research on this issue is limited. Because Indonesia reflects an important developing country under inflation-targeting, this paper investigated the impact of monetary policy and central bank communications on the benchmark interest rates. Unlike other studies, this paper uses two stages. First, we estimate the effect of central bank communication on the inflation expectation gap, that is the difference between the expected inflation and actual one. Second, we use the estimated value of inflation expectation gap to predict the benchmark interest rate.

Our study found evidence that economic agents learn the press release of the Governor Board of Bank of Indonesia decision. The empirical results show that the Central Bank of Indonesia's formal written communication policy had a statistically significant contribution to 3-month-ahead inflation. Accordingly, the central bank monetary policy communications significantly shape the public inflation expectation. In one way this suggests that the informal communication policy reflected in the lagged inflation rate is still a useful tool/predictor of the short-run expected inflation rate when the targeted inflation rate is higher than the actual inflation.

Furthermore, the difference between inflation expectation and actual inflation rates influences the benchmark policy interest rates in Indonesia. In other words, the benchmark interest rates policy can control the inflation rate and 
anchor expectations as required by the inflation-targeting framework. However, the variability of exchange rate fails to describe the policy interest rate. The latter results are consistent with those from standard textbooks and imply substantiation of the impossible trinity - that the three conditions of the flexible exchange rate, monetary independence, and capital mobility, cannot be achieved together.

The main finding of this research is that the Central Bank of Indonesia's communication is a crucial part of the monetary policy implementation since it shapes private inflation expectation with differentiated impacts. Therefore, the optimal design of communication should incorporate the monetary policy decisions together with the communication channels. Although the monetary policy analysis and its contents have shown gradual improvement, the above empirical results suggest that there is still much room for improvement of the Central Bank of Indonesia's monetary policy analysis and its communication. It is also necessary for better management of expectations of stakeholders and to promote the power of monetary policy transmission. Widening central bank communications, include all of social media channels, in a more in-depth way is advisable in future research.

\section{References}

Amato, J. D., Morris, S., \& Shin, H. S. (2002). Communication and Monetary Policy. Oxford Review of Economic Policy, 18(4), 495-502. https://doi.org/10.1093/oxrep/18.4.495

Anwar, M., \& Chawwa, T. (2008). Analisis Ekspektasi Inflasi Indonesia Pasca ITF. Bank Indonesia Working Paper, 09.

Apel, M., \& Grimaldi, M. (2012). The Information Content of Central Bank Minutes. Riksbank Research Paper Series, 92. https://doi.org/10.2139/ssrn.2092575

Bascand, G. (2013). Communication, Understanding, and Credibility. Speech of the Deputy Governor and Head of Operations of the Reserve Bank of New Zealand, to the Admirals Breakfast Club, Auckland.

Blinder, A. S., Ehrmann, M., Fratzscher, M., De Hann, J., \& Jansen, D. J. (2008). Central Bank Communication and Monetary Policy: A Survey of Theory and Evidence. Journal of Economic Literature, 46, 910-45. https://doi.org/10.1257/jel.46.4.910

Bold, S., \& Harris, L. (2018, April). Identifying Monetary Policy Rules in South Africa with Inflation Expectations and Unemployment. WIDER Working Paper 2018/43. https://doi.org/10.35188/UNU-WIDER/2018/485-8

Bulíř, A., Čihák, M., \& Jansen, D. J. (2013). What Drives Clarity of Central Bank Communication About Inflation?. Open Economies Review, 24, 125-45. https://doi.org/10.1007/s11079-012-9259-z

Caldas, M. G. (2012, August). Financial Market Reaction to Central Bank Monetary Policy Communications under an Inflation-Targeting Regime: the Case of Brazil. Cepal Review, 1(7), 165-81.

Dewati, W., Anwar, M., \& Chawwa, T. (2009). Strategi Komunikasi yang Efektif dalam Mengelola Ekspektasi Inflasi. Bank Indonesia Working Paper, 11.

Ehrmann, M. (2015, September). Targeting Inflation from Below: How Do Inflation Expectations Behave?. International Journal of Central Banking, 11(4), 213-49.

Eusepi, S., \& Preston, B. (2010). Central Bank Communication and Expectations Stabilization. American Economic Journal: Macroeconomics, 2(3), 235-71. https://doi.org/10.1257/mac.2.3.235

Flesch, R. (1948). A New Readability Yardstick. Journal of Applied Psychology, 32, 221-33.

Geraats, P. M. (2006). Transparency of Monetary Policy: Theory and Practice. CESifo Economic Studies, 52(1), 111-52.

Goodhart, C. A. E., \& Lim, W. B. (2011). Interest Rate Forecasts: A Pathology. International Journal of Central Banking, 7(2), 135-71.

Hallett, A. H., \& Acocella, N. (2012). Expectations Dynamics Policy Announcements and Limits to Dynamic Inconsistency. Studies in Nonlinear Dynamics and Econometrics, 16(2).

Hansen, S., \& McMahon, M. (2016). Shocking Language: Understanding the Macroeconomic Effects of Central Bank Communication. Journal of International Economics, 99(1), 114-33.

Hayo, B., \& Neuenkirch, M. (2010). Do Federal Reserve Communications Help Predict Federal Funds Target Rate Decisions?. Journal of Macroeconomics, 32(4), 1014-24. https://doi.org/10.1016/j.jmacro.2010.06.003 
Herrero, A. G., Girardin, E., \& Gonzalez, H. (2017). Analyzing the Impact of Monetary Policy on Financial Markets in Chile. Revista De Análisis Económico, 32(1), 3-21. https://doi.org/10.4067/S0718-88702017000100003

Huang, K. X. (2007). Effective Central Bank Communication under Uncertainty. Journal of Economic Issues, 41(3), 661-80. https://doi.org/10.1080/00213624.2007.11507054

Jansen, D. (2011a). Does the Clarity of Central Bank Communication Affect Volatility in Financial Markets?: Evidence from Humphrey-Hawkins Testimonies. Contemporary Economic Policy, 29, 494-509. https://doi.org/10.1111/j.1465-7287.2010.00238.x

Jansen, D. (2011b). Mumbling with Great Incoherence: Was it Really so Difficult to Understand Allan Greenspan?. Economic Letters, 113, 70-2. https://doi.org/10.1016/j.econlet.2011.05.034

Jansen, D., \& De Haan, J. (2007). Were Verbal Efforts to Support the Euro Effective? A Highfrequency Analysis of ECB Statements. European Journal of Political Economy, 23(1), 245-59. https://doi.org/10.1016/j.ejpoleco.2006.09.017

Jansen, D., \& Moessner, R. (2016). Communicating Dissent on Monetary Policy: Evidence from Central Bank Minutes. DNB Working Paper 512. https://doi.org/10.2139/ssrn.2781430

Johansen, S. (1988). Statistical Analysis of Cointegrating Vectors. Journal of Economic Dynamics and Control, 12 , 231-54. https://doi.org/10.1016/0165-1889(88)90041-3

Johansen, S. (1991). Estimation and Hypothesis Testing of Cointegrating Vectors in Gaussian Vector Autoregressive Models. Econometrica, 59, 1551-80. https://doi.org/10.2307/2938278

Kahn, G. (2007). Communicating a Policy Path: The Next Frontier in Central Bank Transparency?. Economic Review, 1, 25-51.

Kincaid, J. P., Fishburne, R. P., Rogers, R. L., \& Chissom, B. S. (1975). Derivation of New Readability Formulas (Automated Readability Index, Fog Count, and Flesch Reading Ease Formula) for Navy Enlisted Personnel. Research Branch Report, 8-75. Chief of Naval Technical Training: Naval Air Station Memphis. https://doi.org/10.21236/ADA006655

Kliesen, K. L., \& Schmid, F. A. (2004, May/June). Monetary Policy Actions, Macroeconomic Data Releases, and Inflation Expectations. Federal Reserve Bank of St. Louis Review, 86(3), 9-21. https://doi.org/10.3886/ICPSR01301

Kuncoro, H. (2015). Inflation Targeting, Exchange Rate Pass-Through, and Monetary Policy Rule in Indonesia. International Journal of Business, Economics and Law, 7(3), 14-25.

Kuttner, K. N. (2004). The Role of Policy Rules in Inflation Targeting. Federal Reserve Bank of St. Louis Review, 86(4), 89-111. https://doi.org/10.20955/r.86.89-112

Kuttner, K. N., \& Posen, A. S. (1999). Does Talk Matter After All? Inflation Targeting and Central Bank Behavior. CFS Working Paper No. 1999/04.

Lee,Y. J., Kim, S. Y., \& Park, K. Y. (2019). Deciphering Monetary Policy Board Minutes through Text Mining Approach: The Case of South Korea. BOK Working Paper No. 2019-1. https://doi.org/10.2139/ssrn.3237909

Luangaram, P., \& Sethapramote, Y. (2016). Central Bank Communication and Monetary Policy Effectiveness: Evidence from Thailand. PIER Discussion Paper No. 20, Puey Ungphakorn Institute for Economic Research, February.

Luangaram, P., \& Wongwachara, W. (2017, February). More Than Words: A Textual Analysis of Monetary Communication Policy. PIER Discussion Papers No. 54, Puey Ungphakorn Institute for Economic Research.

Lucca, D. O., \& Trebbi, F. (2009). Measuring Central Bank Communication: An Automated Approach with Application to FOMC Statements. NBER Working Paper No. 15367, National Bureau of Economic Research.

Martin,V. (2020). Development of Inflation Expectations in Serbia and a Comparative Analysis Journal of Central Banking Theory and Practice, 1, 61-79. https://doi.org/10.2478/jcbtp-2020-0004

Mayandy, K. (2019). Monetary Policy Rules and Macroeconomic Stability: Evidence from Sri Lanka. Bulletin of Monetary Economics and Banking, 22(4), 485-506. https://doi.org/10.21098/bemp.v22i4.1191 
Mendonca, H. F., \& Nicolay, R. T. F. (2017). Is Communication Clarity from Fiscal Authority Useful? Evidence from an Emerging Economy. Journal of Policy Modeling, 39(1), 35-51. https://doi.org/10.1016/j.jpolmod.2016.10.004

Montes, G. C., \& Curi, A. (2017). Disagreement in Expectations about Public Debt, Monetary Policy Credibility, and Inflation Risk Premium. Journal of Economics and Business, 93, 46-61. https://doi.org/10.1016/j.jeconbus.2017.06.003

Montes, G. C., \& Nicolay, R. T. F. (2017). Does Clarity of Central Bank Communication Affect Credibility? Evidences Considering Governor-Specific Effects. Journal of Applied Economics, 49(32), 3163-80.

Montes, G. C., Oliveira, L. V., Curi, A., \& Nicolay, R. T. F. (2016). Effects of Transparency, Monetary Policy Signaling and Clarity of Central Bank Communication on Disagreement about Inflation Expectations. Applied Economics, 48(7), 590-607. https://doi.org/10.1080/00036846.2015.1083091

Nicolay, R. T. F., \& de Oliveira, A. J. (2019). Inflation Volatility, Monetary Policy Signaling and Clarity of the Central Bank Communication: Evidence from an Inflation Targeting Emerging Economy. Journal of Economic Studies, 46(2), 266-83. https://doi.org/10.1108/JES-10-2017-0293

Pesaran, M., \& Shin, Y. (1999). An Auto-regressive Distributed Lag Modeling Approach to Cointegration Analysis. In S. Strom (Ed.), Econometrics and Economic Theory in the 20th Century. Cambridge: Cambridge University Press.

Pincheira, P., \& Calani, M. (2009). Communicational Bias in Monetary Policy: Can Words Forecast Deeds?. Central Bank of Chile Working Papers, 526. https://doi.org/10.1353/eco.2010.0010

Sahminan. (2008). Effectiveness of Monetary Communication Policy in Indonesia and Thailand. BIS Working Papers, No 262, 29 September 2008. https://doi.org/10.2139/ssrn.1333645

Seelajaroen, R., Budsaratragoon, P., \& Jitmaneero, B. (2020, April). Do Monetary Policy Transparency and Central Bank Communication Reduce Interest Rate Disagreement?. Journal of Forecasting, 39(3), 368-93. https://doi.org/10.1002/for.2631

Sturm, J. E., \&De Haan, J. (2011). Does Central Bank Communication Really Lead to Better Forecasts of Policy Decisions? New Evidence-Based on a Taylor Rule Model for the ECB. Review of World Economics, 147(1), 41-58. https://doi.org/10.1007/s10290-010-0076-4

Su, S., Ahmad, A. H., \& Wood, J. (2019). How Effective is Central Bank Communication in Emerging Economies? An Empirical Analysis of the Chinese Money Markets Responses to the People's Bank of China's Policy Communication. Review of Quantitative Finance and Accounting. https://doi.org/10.1007/s11156-019-00822-7

Svensson, L. E. O. (1999). Inflation Targeting as a Monetary Policy Rule. Journal of Monetary Economics, 43, 607-54. https://doi.org/10.1016/S0304-3932(99)00007-0

Szafranek, K. (2017). Flattening of the New Keynesian Phillips Curve: Evidence for an Emerging, Small Open Economy. Economic Modelling, 63, 334-48. https://doi.org/10.1016/j.econmod.2017.01.009

Taylor, J. B. (1999). A Historical Analysis of Monetary Policy Rules. In J. B. Taylor (Ed.), Monetary Policy Rules (pp. 319-48). Chicago, University of Chicago Press. https://doi.org/10.7208/chicago/9780226791265.001.0001

Tomuleasa, I. (2015). Central Bank Communication and Its Role in Ensuring Financial Stability. Procedia Economics and Finance, 20, 637-44. https://doi.org/10.1016/S2212-5671(15)00118-5

Zaheer, S., Khaliq, F., \& Ahmed, W. (2019). Effectiveness of SBP's Monetary Policy Communication. SBP Research Bulletin, 15(1).

Zhou, L., \& Wu, H. (2016). Impact Study of Central Bank Communication to Money Market Benchmark Interest Rate. Open Journal of Social Sciences, 4, 69-78. https://doi.org/10.4236/jss.2016.42011

\section{Copyrights}

Copyright for this article is retained by the author(s), with first publication rights granted to the journal.

This is an open-access article distributed under the terms and conditions of the Creative Commons Attribution license (http://creativecommons.org/licenses/by/4.0/). 